\title{
Sexual Assertiveness Of Adolescent Girls In Medan
}

\author{
Liza Marini1, Rahma Yurliani, Indri Kemala
}

Department of Developmental Psychology

University of Sumatera Utara, Medan, Indonesia

liza1@usu.ac.id ${ }^{1}$

\begin{abstract}
The purpose of the present research was to describe the sexual assertiveness of adolescent girls in Medan. Sample includes 1094 adolescent girls that have been selected using multistage cluster random sampling method, aged 15-18 years and live in Medan. Data for this study were obtained by using Skala Asertivitas Seksual untuk Perempuan Indonesia (SASPI or Sexual Assertiveness Scale for Indonesian Women) developed by Lubis and Oriza based Sexual Assertiveness Scale (SAS). The questionnaires consisted of two dimensions, initiative and rejection. The results showed that there was no subject that categorized into low sexual assertiveness; but rather categorized to the moderate sexual assertiveness category amounted to $49.72 \%$ and categorized into a high sexual assertiveness category amounted $50.28 \%$. If categorization of sexual assertiveness viewed based on initiativeaspect, it can be seen that the low category amounted to $24.95 \%$; moderate category amounted to $74.6 \%$ and the high category amounted to $0.45 \%$. While in rejection aspect showed that no subject is classified into the low category, but rather fall into the moderate category amounted to $11.15 \%$ and high category amounted to $88.85 \%$.
\end{abstract}

Keywords: Sexual assertiveness, adolescent girl

\section{INTRODUCTION}

Free sex behavior was not only prevalent in the general public or among college students, but also has occurred within the ranks of Junior High School students, or among SeniorHigh School students. Ifthe data regarding the involvement of young people in various free sex behavior were viewed, a surprising and alarming numbers can be found.

Surveys of Komisi Penanggulangan AIDS (KPA or National AIDS Commission) in Indonesia recently stated that, there are as many as 66 percent of adolescent girls ages junior high school and senior high school who is no longer a virgin that nationally recorded. This condition means that at school age, they already know free sex (Gunawan in Suparni, 2015). Criminology studies center of Islamic University of Indonesia in Yogyakarta found that there were $26.35 \%$ of 846 wedding events already had sexual intercourse before marriage. Based on these data it is known that $50 \%$ of them resulted in pregnancy (Soetjiningsih in Suparni, 2015). According to a study that examined the sexual behavioral tendencies in four cities showed results of $36.6 \%$ adolescents in the city of Medan, $8.5 \%$ of adolescents in the city of Yogyakarta, $3.4 \%$ of adolescents in the city of Surabaya and $31.1 \%$ of adolescents in the city Kupang has been actively engaged in sexual intercourse (Soetjiningsih in Suparni, 2015).

BKKBN survey results in 2010; approximately $51 \%$ of teenagers in the Jabodetabek area were not a virgin. A total of $4 \%$ of respondents admitted to having sexual intercourse since the age of $16-18$ years, $16 \%$ did it at the age of 13-15 years. The incidence of premarital sex in Surabaya reached $47 \%$, in Bandung and Medan reached 52\%.Free sex among teenagers has an impact on infection of HIV / AIDS cases that tends to flourish in Indonesia. The percentages of favorite place to have sex are in the house as much as $40 \%$, in boarding houseas much as $30 \%$ and in the hotel as much as 30\% (Banun S \& Setyorogo in Suparni, 2015).

Based on the facts above, Medan is one of the cities that showed many cases of sexual behavior among adolescents. In addition, Medan is one of the major cities in Indonesia that have a case of high sexual behaviortendency, with the perpetrators mostly teenagers ages 12-18 years, who were sitting Junior High School and Senior High School. This can be understood because, according to Brown (in Dacey \& Kenny, 1997) adolescents spend the time twice more with 
peers than their parents and other adults, allowing the teen to be affected in negative things.

Nunally and Hawari (in Marini, 2003) concluded that one of the cause of the adolescentsfell into the negative things like drugs, brawling, and free sex was a weak personality.The characteristics include low resistance to pressure; low self-esteem; less able to express themselves; receive feedback, criticized, respects the rights and obligations; less able to control their emotions and aggressiveness and cannot resolve the problems and conflicts well which is closely related to assertiveness.

This statement is supported by research conducted by Family \& Consumer in Ohio, USA, which showed the fact that smoking, use of alcohol, drugs and sexual intercourse related to the inability of young people to be assertive. It was also in line with Novitriani (2013) who stated that many studies have been carried out by universities and research institutions in developed countries regarding peer pressure and smoking habits, use of alcohol and drugs and sexual intercourse by adolescents. The results of previous research revealed that it was all related to the ability of adolescents to be assertive.

Behave assertively are dared to be honest and openly express needs, feelings and thoughts explicitly without offending others or violate the rights of others. Assertive not only convey the personal rights of to others, but also behave assertively means being able to make decisions themselves, thus making it easier to reach the opportunity to achieve what they wanted. In this case, adolescents were able make decisions will behave positively or negatively, and have their own decision to choose a positive social environment that makes them avoidedsexual risks (Marini, 2003).

In the context of sexual, sexual assertiveness concept has been developed as an understanding of the communication strategies used by individuals, especially women to protect sexual health and independence that can be assumed that women have rights over their bodies and the right to express their sexuality (Rickert, Sanghvi, \& Wiemann in Kusuma dewi, 2013).

This was confirmed by a research journal that says that sexual assertiveness has a negative correlation with sexual assault (Livingston, Testa \& VanZile-Tamsenin Diadiningrum, 2014). Dating violence cases occurred in adolescents, one of which can be caused by a lack of assertive ability. Lewis \& Fremouw (in Diadiningrum, 2014) mentioned the lack of assertiveness skill causing the tendency interpersonal problems in setting boundaries and resolve conflicts. The results can lead to vulnerability as victims of aggressive behaviorcrime.

\section{MATERIALS AND METHODS}

This research used descriptive method aimed to provide a description of the research subjects.Based on data from variables derived from a group of studied subjects and is not intended to test the hypothesis. The samples used in this study are sample that fit to the characteristics of the population, namely: adolescent girl, aged 15-18 years old and live in Medan.The sampling technique used in this research was multi-stage cluster random sampling - non proportional.

Data were obtained by using Skala Asertivitas Seksual untuk Perempuan Indonesia (Sexual Assertiveness Scale for Indonesian Womenor SASPI) developed by Lubis and Oryza based on Sexual Assertiveness Scale (SAS). Scale or questionnaire consisted of two dimensions, initiative and rejection. Data analysis method used in this research is descriptive analysis, and the entirequantitative research data processing will be conducted using SPSS version 16.0 for Windows programs.

\section{RESULT AND DISCUSSION}

\section{A. Research Result \\ Sexual Assertiveness Empirical and Hypothetical Data}

Based on empirical data calculation, a minimum score of 145 , a maximum score of 267, Mean218.87 and standard deviation of 19259 were obtained.While based on hypothetical data calculation, a minimum score of 60 , a maximum score of 300, mean 180 and standard deviation 40 were obtained. This data can be seen in Table 1 below: 
Table I

Categorization Based on Hypothetical Mean and Empirical Mean ( $\mathrm{n}=1094)$

\begin{tabular}{|c|c|c|c|c|c|}
\hline \multicolumn{3}{|c|}{ Empirical } & \multicolumn{3}{|c|}{ Hypothetical } \\
\hline $\begin{array}{c}\text { Min- } \\
\text { Max }\end{array}$ & Mean & SD & $\begin{array}{c}\text { Min- } \\
\text { Max }\end{array}$ & $\begin{array}{c}\text { Mea } \\
\mathrm{n}\end{array}$ & SD \\
\hline $145-$ & 218.8 & $\begin{array}{c}19.25 \\
9\end{array}$ & $60-300$ & 180 & 40 \\
267 & 7 & 9 & & & \\
\hline
\end{tabular}

Based on table I it can be seen that thesexual assertiveness empirical mean was higher than the hypothetical mean (218.87> 180 ); thus it can be concluded that the level of assertiveness of the research subjects was higher than the average sexual assertiveness in the general population. If seen from a comparison of standard deviations, the empirical standard deviation was lower than the hypothetical standard deviation $(19.259<40)$; thus it can be concluded that the variance of sexual assertiveness scores are still likely to be low, or in other words, tend to be identical.

\section{Sexual Assertiveness Categorization}

Assertiveness categorizations in this research were based on hypothetical data and were divided into three groups: low, moderate and high. The categorization norms can be seen in the table below:

Table II

Sexual Assertiveness Categorization Norms

\begin{tabular}{|c|c|c|}
\hline Variable & Range of Values & Categorization \\
\hline \multirow{2}{*}{$\begin{array}{c}\text { Sexual } \\
\text { Assertiveness }\end{array}$} & $\mathrm{x}<$ mean-1SD & Low \\
\cline { 2 - 3 } & mean-1SD $\leq \mathrm{x}<$ mean+1SD & Moderate \\
\cline { 2 - 3 } & $\mathrm{x} \geq$ mean+1SD & High \\
\hline
\end{tabular}

Based on the categorization norms in table II and descriptions of sexual assertiveness hypothetical values in Table 6, with a hypothetical mean of 180 and a standard deviation of 40 , thus categorization of sexual assertiveness were obtained as follows:
Table III

Sexual Assertiveness Categorization

\begin{tabular}{|c|c|c|c|c|}
\hline $\begin{array}{c}\text { Variabl } \\
\mathrm{e}\end{array}$ & $\begin{array}{l}\text { Range of } \\
\text { Values }\end{array}$ & $\begin{array}{l}\text { Categor } \\
\text { ization }\end{array}$ & $\begin{array}{c}\text { Freq } \\
\text { uenc } \\
y\end{array}$ & $\begin{array}{l}\text { Percent } \\
\text { age (\%) }\end{array}$ \\
\hline \multirow{3}{*}{$\begin{array}{c}\text { Sexual } \\
\text { Asserti } \\
\text { veness }\end{array}$} & $x<140$ & Low & 0 & $0 \%$ \\
\hline & $\begin{array}{c}140 \leq x \\
<220\end{array}$ & $\begin{array}{c}\text { Modera } \\
\text { te }\end{array}$ & 544 & $49.72 \%$ \\
\hline & $x \geq 220$ & High & 550 & $\begin{array}{c}50.28 \\
\% \\
\end{array}$ \\
\hline
\end{tabular}

Categorization in table III indicates that no subject were classified into the category of low sexual assertiveness; $49.72 \%$ of the subjects were classified into the moderate sexual assertiveness category and $50.28 \%$ subjects were classified into the high sexual assertiveness category.

\section{Sexual Assertiveness Empirical and Hypothetical Value Based on the Aspect}

Description of adolescent sexual assertiveness can also be seen from the aspects that formed it, namely initiative and rejection. Based on 1094 subjects, the data were acquired as follows:

\section{Table IV}

Sexual Assertiveness Empirical and Hypothetical Value Based on the Aspect ( $n=1094)$

\begin{tabular}{|c|c|c|c|c|c|c|}
\hline \multirow{2}{*}{$\begin{array}{c}\text { Soft } \\
\text { Skills }\end{array}$} & \multicolumn{3}{|c|}{ Empirical } & \multicolumn{3}{|c|}{ Hypothetical } \\
\cline { 2 - 7 } Aspects & Min- & Mean & SD & $\begin{array}{c}\text { Min- } \\
\text { Max }\end{array}$ & Mean & SD \\
\hline Initiative & $24-$ & 61.83 & 13.352 & $24-$ & 72 & 19.33 \\
& 104 & & & 120 & & \\
\hline Rejection & $90-$ & 157.03 & 18.831 & $36-$ & 108 & 24 \\
& 180 & & & 180 & & \\
\hline
\end{tabular}

Based on table IV it can be seen that on the aspects of the initiative, the empirical mean was lower than the hypothetical mean $(61.83<72)$;it can be concluded that the research subjects' initiative aspect was lower than the average initiativeaspect on the general population. Based on the standard deviation value, it can be seen that the empirical standard deviation was lower than the hypothetical standard deviation; thusit meant that score variation of initiative aspect was still relatively low, or tend to be identical.

On the aspect of rejection, it can be seen that the empirical mean was higher than the 
hypothetical mean (157.03> 108). It can be concluded that the research subjects' rejection aspect was higher than the average rejection aspect on the general population. Based on the standard deviation, the empirical standard deviation values on the rejection aspectwas lower than thehypothetical standard deviation was obtained (18 $881<24)$, which meant that the score variation of rejection aspect tends to be low or identical.

\section{Sexual Assertiveness Categorization Based on the Aspect}

Sexual assertiveness categorizations in this research were based on hypothetical data that weredivided into three groups: low, moderate and high. This categorization can be seen as follows:

\section{Table V}

Sexual Assertiveness Categorization Based on the Aspect

\begin{tabular}{|c|c|c|c|c|}
\hline \multirow{2}{*}{ Aspect } & $\begin{array}{c}\text { Range of } \\
\text { Values }\end{array}$ & $\begin{array}{c}\text { Categoriz } \\
\text { ation }\end{array}$ & $\begin{array}{c}\text { Frequenc } \\
\mathrm{y} \\
(\%)\end{array}$ & $\begin{array}{c}\text { Frequenc } \\
\mathrm{y}(\%)\end{array}$ \\
\hline \multirow{3}{*}{ Initiative } & $\mathrm{x}<53$ & Low & 273 & 24.95 \\
\cline { 2 - 5 } & $53 \leq \mathrm{x}<91$ & Moderate & 816 & 74.6 \\
\cline { 2 - 5 } & $\mathrm{x} \geq 91$ & High & 5 & 0.45 \\
\hline \multirow{3}{*}{ Rejection } & $\mathrm{x}<84$ & Low & 0 & 0 \\
\cline { 2 - 5 } & $84 \leq \mathrm{x}<132$ & Moderate & 122 & 11.15 \\
\cline { 2 - 5 } & $\mathrm{x} \geq 132$ & High & 972 & 88.85 \\
\hline
\end{tabular}

Table $\mathrm{V}$ shows the sexual assertiveness categorization based on the aspect. On initiativeaspect, it can be seen that the low category amounted to $24.95 \%$; moderate category amounted to $74.6 \%$ and the high category amounted to $0.45 \% .0 n$ rejectionaspect, it can be seen that the low category amounted to $0.00 \%$; moderate category amounted to $11.15 \%$ and the high category amounted to $88.85 \%$.

\section{B. Research Discussion}

Based on the research results it can be seen that thesexual assertiveness empirical mean washigherthan the hypothetical mean (218.87> 180 ); thus it can be concluded that the level of assertiveness of the research subjects was higher than the average sexual assertiveness in the general population.Also based on the results of sexual assertiveness categorization, there are two categories, high and moderate $50.28 \%$ high and $49.72 \%$ moderate); this indicates that sexual assertiveness of adolescent girls in Medan is relatively high. This was in line with the research conducted by Tholense \& Raharjo (2013) regarding Sexual Assertiveness and Premarital Sex Behavior on Student, where the results showed that sexual assertiveness of the subjects in this research were in the high category. This means that the subjectsare able to defend their sexual rights properly in order to not being abused by others as well as their partner.

According to Lubis and Oriza (2005) sexual assertiveness is the ability to retain sexual right to be able to take sexual decisions while still giving appreciation to the rights of others and without hurting others or their partner and express themselves in an honest and proper way with a sense of comfort without feeling worried that interfering thus encouraging the establishment of equalities and similarities in the relationship with their partner.

Assertive behavior is not an easy thing to do, especially for teenagers. But it is possible to do, as stated by Willis \& Daisley (1995) that assertiveness is a form of behavior and not a personality trait one's innate, so it can be studied although the pattern of one's habits affect the learning process (Pentz in Rakos, 1991). Assertive behavior can be learned naturally from the environment. Environment is meant here is the family, culture, age and gender. This is consistent with the statement Rathus and Nevis (in Widjaja \& Wulan, 1998) which states that assertive behavior is learned patterns of the environment as a reaction to social situations in life.

In this case most of the samples of this study is the background of the Batak tribe so that they bring the characters of the Batak is open, spontaneous and brave that leads to high assertive behavior (Tinambunan, 2010). It also added that the younger generation tends to be more assertive since learning of gender roles that are given at the moment is more modern than ever before (Lubis and Oryza, 2005) with parenting also gives children the opportunity to express opinions and argue. 
Based on initiativeaspect, it can be seen that the low category amounted to $24.95 \%$ of the subjects; moderate category amounted to $74.6 \%$ of the subjects and the high category amounted to $0: 45 \%$ of the subjects. Based on rejection aspect, showed that no subject is classified into the low category,but rather fall into the moderate category amounted to $11.15 \%$ of the subjects and high category amounted to $88.85 \%$ of the subjects.

Based on the theory that someone who has a high assertiveness has a tendency that a person has the initiative and the rejection tends to be high as well. From the results show that the adolescent girls in Medan has initiative aspect classified as moderate and rejection aspectclassified as high, so they are quite capable of resisting and initiative sexual behavior with they partner. Adolescent girl was able to resist when the couple wanted to kissing, touching parts of her body, provide stimulation to the brast, giving stimulus to the genital and invite sexual intercourse.

But on the other sideadolescent girl have enough initiative to express his desire in sexual behaviour with their partner, this is what might make the high rate of teenage sexual behavior high if not accompanied by strong religious foundation and the planting of enough parental moral education of their childhood to adolescence.

Also based on the research results comparison to standards deviationscould be seen, the result was the empirical standard deviation is lower than the hypothetical standard deviation $(19.259<40)$; thus it can be concluded that thesexual assertiveness score variation are still likely to be low, or in other words, tend to be identical.It can be caused by variables of this research are quite sensitive, so it is likely for the subject to be faking good or have a high social desirability.Social desirability is the answer or individual response to the applied questions where the subject seeks to increase the commonality with characteristics of the community and lowering the characteristics that are not expected by the community.In short it can be said that social desirability confirms the good and hide the bad (Sjostrom \& Holst in Widhiarso 2011).

\section{CONCLUSION}

The research results showed that sexual assertiveness of adolescent girls in Medan is relatively high, which is the subjects are able to defend their sexual rights properly in order to not being abused by others as well as their partner.The younger generation tends to be more assertive because of gender roles learning that given this days is more modern than ever before. Gender roles learning that received by the older generation lead them to believe that the initiative in sexual activities were more appropriately done by men. Adolescents has been affected by the customs that exist in Medan where the dominant tribes is Batak (straightforward, open and spontaneous).

Adolescent girls in Medan have initiative aspect classified as moderate and rejection aspectclassified as high, so they are quite capable of resisting and initiative sexual behavior with they partner. Adolescent girl was able to resist when the couple wanted to kissing, touching parts of her body, provide stimulation to the breast, giving stimulus to the genital and invite sexual intercourse. Adolescent girlsin Medan also have enough initiative to express his desire in sexual behaviour with their partner.

As a note, this study use SASPI scale where the items has high social desirable and not accordance with culture in Medan. The contents of item scale its about sexual behavior, so it tend to cause a negative response. It is likely for the subject to be faking goodwhich is item contain high social desirability.

\section{REFERENCES}

Dacey, J \& Kenny, M. (1997). Adolescent Development, Ed.2.,Brown \& Benchmark pub, USA.

Diadiningrum, J. R \& Endrijati, H. (2014). The relationship between attitude Assertiveness with trend Become Victims of Violence in Teen Dating Reviewed,Journal of Educational \& Developmental Psychology \&, No.2, Vol.3, 97-102.

Kusumadewi, N.S. (2013). The relationship between sexual assertiveness in sexual 
risk-taking behavior on the students in Jakarta, Skripsi, Faculty of Psychology, Universitas Binus, Jakarta.

Lubis, D.U \& Oriza, D. (2005). Sexual assertiveness for Indonesian Female (an effort of SASPI scale),Skripsi, Faculty of Psychology, Universitas Indonesia, Jakarta.

Marini, L \& Andriani, E. (2003). The differences adolescents assertiveness in terms of parenting style, Skripsi, Study Program of Psychology, Universitas Sumatera Utara, Medan.

Morokoff, P.J., Quina, K., Harlow, L.L., Whitmire, L., Grimley, D.M., Gibson, P.R., \& Burkholder, G.J. (1997). Sexual Assertiveness Scale (SAS) for Women: Development and Validation, Journal of Personality and Social Psychology, No.4, Vol.73, 790-804.

Novitriani, S. (2013). Development Assertive Behavior In Adolsecents.Retrieved August 2016 from http://www. bkkbn.go.id.

Rakos, R.F. (1991). Assertive Behavior : Theory, Research \& Training, Routledge, Chapman \& Hall Inc, New York.

Suparni, E. (2015). The relationship between permissive parenting attitudes toward sexual behavior in adolescents, Skripsi, Faculty of Psychology, Universitas Muhammadiyah Surakarta, Surakarta.

Tholense \& Raharjo. (2013). Assertiveness Premarital Sex Sexual Behavior in Students, Journal of Ulayat Psychology, No.2, Vol.1, 201-206.

Widhiarso, Wahyu. (2011). Orientation Social Decency And Response Measurement Trickery On Work In Context Selection, Benefit Journal of Management and Business, No.2, Vol.15, 76-90.

Widjaja, P.D.C., \& Wulan, R. (1998). Relation Between Assertiveness and Maturity with Neurotic Trends in Adolescents. Journal of Psychology, 2, 56-62.

Willis \& Daisley. (1995). The Assertive Trainer: A Practical Handbook on Assertiveness For Trainers \& Running Assertiveness Courses. McGraw Hill Comp. London. 